University of Nebraska - Lincoln

DigitalCommons@University of Nebraska - Lincoln

Faculty Papers and Publications in Animal

Science

Animal Science Department

October 1996

\title{
Estimation of Direct and Maternal Breed Effects for Prediction of Expected Progeny Differences for Birth and Weaning Weights in Three Multibreed Populations
}

\author{
F. A. Rodriguez-Almeida \\ University of Nebraska-Lincoln \\ L. Dale Van Vleck \\ University of Nebraska-Lincoln, dvan-vleck1@unl.edu \\ K. E. Gregory \\ Roman L. Hruska U.S. Meat Animal Research Center, USDA-ARS
}

Follow this and additional works at: https://digitalcommons.unl.edu/animalscifacpub

Part of the Animal Sciences Commons

Rodriguez-Almeida, F. A.; Van Vleck, L. Dale; and Gregory, K. E., "Estimation of Direct and Maternal Breed Effects for Prediction of Expected Progeny Differences for Birth and Weaning Weights in Three Multibreed Populations" (1996). Faculty Papers and Publications in Animal Science. 266.

https://digitalcommons.unl.edu/animalscifacpub/266

This Article is brought to you for free and open access by the Animal Science Department at DigitalCommons@University of Nebraska - Lincoln. It has been accepted for inclusion in Faculty Papers and Publications in Animal Science by an authorized administrator of DigitalCommons@University of Nebraska - Lincoln. 


\title{
Estimation of Direct and Maternal Breed Effects for Prediction of Expected Progeny Differences for Birth and Weaning Weights in Three Multibreed Populations
}

\author{
F. A. Rodríguez-Almeida, ${ }^{*, 1}$ L. D. Van Vleck, ${ }^{\dagger}$ and K. E. Gregory ${ }^{\ddagger}$ \\ *Facultad de Zootecnia, Universidad Autónoma de Chihuahua, Apdo. Postal 4-28, Chihuahua, \\ México C.P. 31031 and Roman L. Hruska U.S. Meat Animal Research Center, ARS, USDA, \\ †Lincoln, NE 68583-0908 and ₹Clay Center, NE 68933-0166
}

\begin{abstract}
Direct and maternal breed effects on birth and 200-d weights were estimated for nine parental breeds (Hereford $[\mathrm{H}]$, Angus $[\mathrm{A}]$, Braunvieh $[B]$, Limousin [L], Charolais [C], Simmental [S], Gelbvieh [G], Red Poll [R], and Pinzgauer [P]) that contributed to three composite populations (MARC I = $1 / 4 \mathrm{~B}, 1 / 4 \mathrm{C}, 1 / 4 \mathrm{~L}, 1 / 8 \mathrm{H}, 1 / 8 \mathrm{~A}$; MARC II $=1 / 4 \mathrm{G}, 1 / 4 \mathrm{~S}, 1 / 4 \mathrm{H}, 1 / 4 \mathrm{~A}$; and MARC III $=1 / 4 R, 1 / 4 \mathrm{P}, 1 / 4 \mathrm{H}, 1 / 4 \mathrm{~A}$ ). Records from each population, the composite plus pure breeds and crosses used to create each composite, were analyzed separately. The animal model included fixed effects of contemporary group (birth year-sex-dam age), proportions of individual and maternal heterosis and breed inheritance as covariates, and random effects of additive direct genetic (a) and additive maternal genetic $(m)$ with covariance $(a, m)$, permanent en-
\end{abstract}

vironment, and residual. Sampling correlations among estimates of genetic fixed effects were large, especially between direct and maternal heterosis and between direct and maternal breed genetic effects for the same breed, which were close to -1 . This resulted in some large estimates with opposite sign and large standard errors for direct and maternal breed genetic effects. Data from a diallel experiment with $\mathrm{H}, \mathrm{A}, \mathrm{B}$, and $\mathrm{R}$ breeds, from grading up and from a top cross experiment were required to separate breed effects satisfactorily into direct and maternal genetic effects. Results indicate that estimation of direct and maternal breed effects needed to predict hybrid EPD for multibreed populations from field data may not be possible. Information from designed crossbreeding experiments will need to be incorporated in some way.

Key Words: Breeds, Crossbreeding, Beef Cattle

J. Anim. Sci. 1997. 75:1203-1212

\section{Introduction}

Hybrid beef cattle EPD have been proposed (Golden et al., 1994; Wilton and Miller, 1994) to allow evaluation of additive genetic merit of purebred and crossbred cattle in multibreed populations as a tool for efficient use of crossbreeding programs.

Models proposed for genetic evaluation in multibreed populations (EIzo and Famula, 1985; Arnold et al., 1992) involve estimation of additive genetic breed effects, which form part of EPD used to compare animals of different breed composition. Use of algorithms to account for differences in groups going through different levels of selection (Westell et al., 1988; Van Vleck, 1990) has been recommended to account for differences in breeds and to reduce costs of solving equations corresponding to genetic grouping.

\footnotetext{
${ }^{1}$ To whom correspondence should be addressed.

Received May 23, 1996.

Accepted October 28, 1996.
}

Elzo and F amula (1985) warned that for data from open crossbreeding programs, problems of confounding with genetic fixed effects could exist due to empty subclasses. Such confounding could be difficult to detect in evaluations using the Westell et al. (1988) algorithm. The purpose of this study was to investigate the effect of data structure on estimation of direct and maternal breed effects fitted as covariates in models for birth and 200-d weights of three multibreed populations of beef cattle.

\section{Materials and Methods}

\section{Description of Data}

The Germ Plasm Utilization (GPU) project at the Roman L. Hruska U.S. Meat Animal Research Center (MARC), Clay Center, Nebraska, consisted of an experiment with three composite populations. The data structure is similar to the structure of field data for multibreed populations. Those data were used in 
Table 1. Matings to establish composites, breed composition, and levels of heterozygosity in different generations of the composites

\begin{tabular}{|c|c|c|c|}
\hline \multirow[b]{2}{*}{ Item } & \multicolumn{3}{|c|}{ Composite population } \\
\hline & MARC I & MARC II & MARC III \\
\hline Parents of $F_{1}$ generation ${ }^{a}$ & $\begin{array}{l}(C \times L H) \times(B \times L A) \text { or } \\
(C \times L A) \times(B \times L H) \\
\text { reciprocals }\end{array}$ & $(G H) \times(S A)$ or $(G A) \times(S H)$ & $\begin{array}{l}(P A) \times(R H) \text { or }(P A) \times(H R) \\
\quad \text { reciprocals }\end{array}$ \\
\hline $\begin{array}{l}\text { Breed composition of } F_{1} \text { and } \\
\text { subsequent generations }\end{array}$ & $.25 \mathrm{~B}, .25 \mathrm{C}, .25 \mathrm{~L}, .125 \mathrm{H}, .125 \mathrm{~A}$ & $.25 \mathrm{G}, .25 \mathrm{~S}, .25 \mathrm{H}, .25 \mathrm{~A}$ & $.25 \mathrm{P}, .25 \mathrm{R}, .25 \mathrm{H}, .25 \mathrm{~A}$ \\
\hline $\mathrm{F}_{1}$ heterozygosity ${ }^{b}$ & $.94 \mathrm{H}^{\prime}+1.00 \mathrm{H}^{\mathrm{M}}$ & $1.00 \mathrm{H}^{\mathrm{I}}+1.00 \mathrm{H}^{\mathrm{M}}$ & $1.00 \mathrm{H}^{\mathrm{I}}+1.00 \mathrm{H}^{\mathrm{M}}$ \\
\hline $\mathrm{F}_{2}$ heterozygosity & $.78 \mathrm{H}^{\prime}+.94 \mathrm{H}^{\mathrm{M}}$ & $.75 \mathrm{H}^{\prime}+1.00 \mathrm{H}^{\mathrm{M}}$ & $.75 \mathrm{H}^{\prime}+1.00 \mathrm{H}^{\mathrm{M}}$ \\
\hline$F_{2}$ heterozygosity & $.78 \mathrm{H}^{\prime}+.78 \mathrm{H}^{\mathrm{M}}$ & $.75 \mathrm{H}^{\mathrm{I}}+.75 \mathrm{H}^{\mathrm{M}}$ & $.75 \mathrm{H}^{\prime}+.75 \mathrm{H}^{\mathrm{M}}$ \\
\hline
\end{tabular}

${ }^{a}$ Composite populations were established from the same animals used in the purebred foundation populations; $\mathrm{C}=\mathrm{Charolais}$, $\mathrm{L}=$ Limousin, $\mathrm{H}=$ Hereford, $\mathrm{B}=$ Braunvieh, $\mathrm{A}=$ Angus, $\mathrm{G}=$ Gelbvieh, $\mathrm{S}=$ Simmental, $\mathrm{P}=$ Pinzgauer, $\mathrm{R}=\mathrm{Red}$ Poll.

${ }^{\mathrm{b}} \mathrm{H}^{\prime}$ denotes individual heterozygosity in the progeny of a given generation, and $\mathrm{H}^{\mathrm{M}}$ denotes maternal heterozygosity in their dams.

the present study. Gregory et al. (1991) gave a complete description of formation of the composites including the origins of the purebred animals that contributed to formation of the composites and of the management of the animals.

A summary of the matings to establish the composites, including the breed composition and level of heterozygosity in the different generations of the composites, is given in Table 1 . In this experiment the $\mathrm{F}_{1}$ is defined as the first generation that reflects the final breed composition of a composite population. Composites were formed from the same sires and dams that were represented in the nine contributing parental breeds (Red Poll, Hereford, Angus, Limousin, Braunvieh, Pinzgauer, Gelbvieh, Simmental, and Charolais). The level of heterozygosity was stabilized in the second generation for the direct part and in the third generation for the maternal part. Contributing purebred contemporaries were maintained for Pinzgauer since 1982 and for all other breeds since 1978, when the first calves were born in the experiment.

The Braunvieh population averaged between 3/4 and $7 / 8$ Braunvieh and was established by using semen from nine Braunvieh sires originating in Switzerland and Germany on a foundation of purebred Brown Swiss females obtained from dairy herds in Wisconsin and Minnesota as calves in 1967 and 1968. Breed substitution from Brown Swiss to Braunvieh started in 1969. The Simmental, Limousin, Gelbvieh, and Pinzgauer populations were established by mating 20 or more sires of each breed to purebred females from the same Hereford and Angus populations used in the experiment (except as noted) and subsequently by repeatedly backcrossing to the four breeds of sire. Grade-up programs to these breeds started at MARC in 1969 for Simmental, in 1970 for Limousin, in 1975 for Gelbvieh, and in 1977 for Pinzgauer. A sample of 3/4 Gelbvieh females bred to produce 7/8 Gelbvieh progeny was purchased to augment the Gelbvieh population in 1977. These females were graded up from a female population of Charolais $\times$ Angus with the same sample of Gelbvieh sires used in the Gelbvieh grade-up program at MARC. The Charolais population was established with the purchase of purebred Charolais females in 1977 and was augmented by Charolais grade-up from Angus $\times$ Hereford females at MARC starting in 1967. Charolais sires were sampled from a broad genetic base. The Red Poll population was established from purebred females purchased from several sources in 1966, 1967, and 1968 with sires sampled from a broad genetic base. The Hereford and Angus breeds have been maintained as closed populations (except as noted) since 1960. A sample of Hereford males and females was added in 1966, but this sample did not produce any male progeny that were used to maintain the population. A sample of Angus sires introduced in 1967 and $1968 \mathrm{did}$ not produce males used to maintain the population.

Analyses were performed on two sets of data with different structure for each of the three multibreed populations.

Data Set 1. A first analysis was with records for each of the multibreed populations including the composites plus the contemporary purebreds, until 1992, and the purebred and crossbred ancestors of the animals in the composite, back to 1968. The structures of the data sets are shown in Tables 2, 3, and 4 for the MARC I, MARC II, and MARC III populations, respectively.

Data Set 2. For the second analysis for each multibreed population, extra data were incorporated to improve estimates of direct and maternal breed effects. The structures of these data sets are shown in Tables 5, 6, and 7. Some data came from a diallel cross experiment in 1973 to 1974, involving the Braunvieh, Red Poll, Hereford, and Angus breeds. Gregory et al. (1978) and Dearborn et al. (1987) described the origin and management of the animals. Braunvieh and Red Poll animals were from the same populations as those in the GPU program. The same was true for Hereford and Angus sires. Hereford and Angus dams were sampled as calves from commercial producers in 
Table 2. Structure of data set 1 for the MARC I population ${ }^{a}$

\begin{tabular}{|c|c|c|}
\hline Breed & $\begin{array}{l}\text { Period of } \\
\text { births }\end{array}$ & $\begin{array}{c}\text { Animals } \\
\text { with } \\
\text { birth } \\
\text { weight }\end{array}$ \\
\hline Angus (A) & 1968-1992 & 2,293 \\
\hline Hereford $(\mathrm{H})$ & 1968-1992 & 1,774 \\
\hline Braunvieh (B) & 1969-1992 & 1,480 \\
\hline Limousin (L) & 1978-1992 & 1,563 \\
\hline Charolais (C) & 1978-1992 & 1,481 \\
\hline $\mathrm{L} \times \mathrm{H}$ & 1970-1972 & 84 \\
\hline$L \times A$ & 1970-1972 & 62 \\
\hline $\mathrm{B} \times \mathrm{LH}$ & 1976-1979 & 67 \\
\hline$B \times L A$ & $1976-1979$ & 78 \\
\hline $\mathrm{C} \times \mathrm{LH}$ & 1976-1979 & 40 \\
\hline$C \times L A$ & 1976-1979 & 63 \\
\hline$(B \times L H) \times(C \times L A)^{b}$ & 1978-1983 & 145 \\
\hline$(B \times L A) \times(C \times L H)^{b}$ & 1978-1983 & 80 \\
\hline$(C \times L H) \times(B \times L A)^{b}$ & 1978-1983 & 191 \\
\hline$(C \times L A) \times(B \times L H)^{b}$ & 1978-1983 & 167 \\
\hline $\mathrm{F}_{2}$ & 1981-1990 & 1,081 \\
\hline$>\mathrm{F}_{2}$ & 1984-1992 & 1,424 \\
\hline Total animals with birth weight & & 12,073 \\
\hline Total animals with $200-d$ weight & & 11,069 \\
\hline No. of animals in $A^{-1}$ & & 15,549 \\
\hline
\end{tabular}

aData set 1 included records of composite animals, their ancestors, and their contemporary purebreds.

${ }^{b}$ Progeny from these matings were defined as the $F_{1}$ generation; the $F_{2}$ were the progeny resulting from inter se matings among $F_{1}$ animals.

western Nebraska. Three-way crosses were obtained in 1975 and 1976. These crossbred animals were included in the populations that had the same contributing breeds. All data from the grade-up programs that were not included in the first analyses were added in these second analyses. Other extra data came from the Germ Plasm Evaluation (GPE) program at MARC, which consisted of a top cross experiment involving crosses of different sire breeds to Hereford and Angus dams. Records of progeny sired by Limousin (1970 to 1972), Simmental (1970 to 1972), and Gelbvieh (1973 to 1974) bulls were included in the second analyses. Records on $F_{1}$ females were not included because they were mated to breeds of sire that were not used in the GPU project. Description of animals and management was given by Smith et al. (1976) and Gregory et al. (1979). Most male calves in the GPE project were castrated before weaning, so 200-d weights of these steers were excluded from the analyses.

\section{The Model}

In general, models that have been proposed for data from multibreed populations (E Izo and Famula, 1985; Arnold et al., 1992) involve contemporary group fixed effects, direct and maternal additive genetic fixed and random effects, and fixed and random effects due to genetic interactions, in addition to other random effects including the residuals. These models consider the most important factors affecting records of animals from multibreed populations; however, with the type of data available, with many empty cells in the design, it is not possible to get good estimates for some of the parameters. To analyze the data in the present study, a simplified version of the animal model presented by Arnold et al. (1992) was used. The general structure of the model can be represented as:

$$
\begin{gathered}
y_{i j k}=S U_{k}+p_{i} h^{l}+p_{j} h^{M}+\sum_{l=1}^{b} f_{i l} B_{l}{ }^{l} \\
+\sum_{l=1}^{b} f_{j l} B_{l}{ }^{M}+a_{i}+m_{j}+c_{j}+e_{i j k}
\end{gathered}
$$

where

$y_{i j k}$ is the birth or 200-d weight measured on the $i^{\text {th }}$ animal from the $\mathrm{j}^{\text {th }}$ dam and in the $k^{\text {th }}$ contemporary group;

$S U_{k}$ is the fixed contemporary group effect defined by the $k^{\text {th }}$ birth year-sex-age of dam subclass. Sex levels consisted of bulls and heifers, and age of dam levels were $2,3,4$, and $>4 \mathrm{yr}$;

$\mathrm{p}_{\mathrm{i}}$ and $\mathrm{p}_{\mathrm{j}}$ are the expected proportions of heterozygosity for the $\mathrm{i}^{\text {th }}$ animal and the $\mathrm{j}^{\text {th }}$ dam, respectively;

Table 3. Structure of data set 1 for the

\begin{tabular}{|c|c|c|}
\hline Breed & $\begin{array}{l}\text { Period of } \\
\text { births }\end{array}$ & $\begin{array}{c}\text { Animals } \\
\text { with } \\
\text { birth } \\
\text { weight }\end{array}$ \\
\hline Angus (A) & 1968-1992 & 2,293 \\
\hline Hereford $(\mathrm{H})$ & 1968-1992 & 1,774 \\
\hline Simmental (S) & 1978-1992 & 1,494 \\
\hline Gelbvieh (G) & 1978-1992 & 1,303 \\
\hline $\mathrm{S} \times \mathrm{H}$ & 1970-1972 & 89 \\
\hline$S \times A$ & 1970-1972 & 122 \\
\hline $\mathrm{G} \times \mathrm{H}$ & 1976-1977 & 11 \\
\hline$G \times A$ & 1976-1977 & 6 \\
\hline$(\mathrm{GH}) \times(\mathrm{SA})^{\mathrm{b}}$ & $1978-1982$ & 431 \\
\hline$(\mathrm{GA}) \times(\mathrm{SH})^{\mathrm{b}}$ & 1978-1982 & 297 \\
\hline $\mathrm{F}_{2}$ & 1980-1990 & 1,330 \\
\hline$>\mathrm{F}_{2}$ & 1983-1992 & 1,717 \\
\hline Total animals with birth weight & & 10,867 \\
\hline Total animals with $200-d$ weight & & 9,920 \\
\hline No. of animals in $A^{-1}$ & & 14,103 \\
\hline
\end{tabular}
MARC II population ${ }^{a}$

aData set 1 included records of composite animals, their ancestors, and their contemporary purebreds.

${ }^{b}$ Progeny from these matings were defined as the $F_{1}$ generation; the $F_{2}$ were the progeny resulting from inter se matings among $F_{1}$ animals. 
Table 4. Structure of data set 1 for the MARC III population ${ }^{a}$

\begin{tabular}{|c|c|c|}
\hline Breed & $\begin{array}{l}\text { Period of } \\
\text { births }\end{array}$ & $\begin{array}{l}\text { Animals } \\
\text { with } \\
\text { birth } \\
\text { weight }\end{array}$ \\
\hline Angus (A) & 1968-1992 & 2,293 \\
\hline Hereford $(\mathrm{H})$ & $1968-1992$ & 1,774 \\
\hline Pinzgauer $(P)$ & $1982-1992$ & 883 \\
\hline Red Poll ( $R$ ) & 1968-1992 & 1,462 \\
\hline$H \times R$ & 1978 & 32 \\
\hline $\mathrm{R} \times \mathrm{H}$ & 1978 & 99 \\
\hline$P \times A$ & 1978-1979 & 76 \\
\hline$(R H) \times(P A)^{b}$ and $(H R) \times(P A)^{b}$ & $1980-1984$ & 157 \\
\hline$(P A) \times(R H)^{b}$ & 1980-1984 & 299 \\
\hline$(P A) \times(H R)^{b}$ & 1980-1984 & 99 \\
\hline $\mathrm{F}_{2}$ & $1982-1990$ & 925 \\
\hline$>\mathrm{F}_{2}$ & 1985-1992 & 1,223 \\
\hline Total animals with birth weight & & 9,322 \\
\hline Total animals with $200-d$ weight & & 8,596 \\
\hline No. of animals in $A^{-1}$ & & 12,378 \\
\hline
\end{tabular}

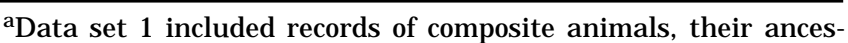
tors, and their contemporary purebreds.

brogeny from these matings were defined as the $F_{1}$ generation; the $F_{2}$ were the progeny resulting from inter se matings among $F_{1}$ animals.

$\mathrm{h}^{\mathrm{I}}$ and $\mathrm{h}^{\mathrm{M}}$ are the direct and maternal heterosis effects, respectively, fitted as covariates. The assumption is that heterosis effects for any breed combination are the same. This assumption may or may not be realistic, but with the information available this was all that could be estimated;

$f_{i l}$ and $f_{j l}$ are the expected fractions of genes that the $i^{\text {th }}$ animal and the $\mathrm{j}^{\text {th }}$ dam, respectively, received from the th $^{\text {th }}$ breed;

$\mathrm{B}_{1}{ }^{\mathrm{I}}$ and $\mathrm{B}_{1}{ }^{\mathrm{M}}$ are the direct and maternal genetic effects, respectively, of the $1^{\text {th }}$ breed, fitted as covariates;

$a_{i}$ is the random additive genetic effect for the $i^{\text {th }}$ animal;

$m_{j}$ and $c_{j}$ are the random additive genetic and permanent environmental maternal effects of the $j^{\text {th }}$ dam;

$e_{i j k}$ is the random residual effect.

In matrix notation the model equation can be expressed as follows:

$$
\begin{aligned}
\mathbf{y}=\mathbf{X} \beta & +\mathbf{H h}+\mathbf{Q}_{\mathbf{l}} \mathbf{g}+\mathbf{Q}_{M} \mathbf{d}+\mathbf{Z}_{\mathbf{I}} \mathrm{a} \\
& +Z_{M} \mathbf{m}+\mathbf{W c}+\mathbf{e}
\end{aligned}
$$

where

$\mathbf{y}$ is the vector of observations,

$\beta$ is the vector of fixed contemporary group effects, $\mathbf{h}$ is the vector of direct and maternal heterosis effects,

$\mathbf{g}$ and $\mathbf{d}$ are the vectors of direct and maternal breed fixed effects, respectively,

$\mathbf{a}$ is the vector of random additive direct genetic effects,

$\mathbf{m}$ and $\mathbf{c}$ are the vectors of random additive genetic and permanent environmental maternal effects,

e is the vector of residuals,

$\mathbf{X}$ is an incidence matrix with zeros and ones relating observations to contemporary group fixed effects,

$\mathbf{H}$ is an incidence matrix relating observations to direct and maternal heterosis effects through the corresponding $p_{i}$ and $p_{j}$ values,

$\mathbf{Q}_{\mid}$and $\mathbf{Q}_{\mathbf{M}}$ are incidence matrices relating observations to direct and maternal breed effects through the corresponding $f_{i l}$ and $f_{j l}$ fractions, respectively,

Table 5. Structure of data set 2 for the

\begin{tabular}{|c|c|c|}
\hline Breed & $\begin{array}{l}\text { Period of } \\
\text { births }\end{array}$ & $\begin{array}{c}\text { Animals } \\
\text { with } \\
\text { birth } \\
\text { weight }\end{array}$ \\
\hline Data set $1^{b}$ & 1968-1992 & 12,073 \\
\hline Angus (A) & 1973-1974 & 129 \\
\hline Hereford $(\mathrm{H})$ & 1973-1974 & 86 \\
\hline Braunvieh (B) & 1973-1974 & 26 \\
\hline Limousin ( $\mathrm{L})$ & 1977-1978 & 8 \\
\hline Charolais (C) & $1976-1985$ & 780 \\
\hline $\mathrm{H} \times \mathrm{A}$ and reciprocal & 1973-1976 & 293 \\
\hline $\mathrm{H} \times \mathrm{B}$ and reciprocal & 1973-1976 & 164 \\
\hline$A \times B$ and reciprocal & 1973-1976 & 185 \\
\hline $\mathrm{C} \times \mathrm{H}$ or $\mathrm{A}$ & 1968-1969 & 186 \\
\hline $\mathrm{L} \times \mathrm{H}$ or $\mathrm{A}$ & 1970-1972 & 574 \\
\hline$A \times(H B)$ & 1975-1976 & 6 \\
\hline$A \times(B H)$ & $1975-1976$ & 26 \\
\hline$H \times(B A)$ & 1975-1976 & 25 \\
\hline$H \times(A B)$ & 1975-1976 & 6 \\
\hline Backcrosses H-A & 1975-1976 & 13 \\
\hline $\mathrm{C} \times(\mathrm{C} \times \mathrm{H}$ or $\mathrm{A})$ & 1970-1978 & 559 \\
\hline $\mathrm{L} \times(\mathrm{L} \times \mathrm{H}$ or $\mathrm{A})$ & 1972-1976 & 433 \\
\hline $\mathrm{C} \times \mathrm{C} \times(\mathrm{C} \times \mathrm{H}$ or $\mathrm{A})$ & 1972-1983 & 480 \\
\hline $\mathrm{L} \times \mathrm{L} \times(\mathrm{L} \times \mathrm{H}$ or $\mathrm{A})$ & 1975-1978 & 160 \\
\hline Total animals with birth weight & & 16,212 \\
\hline Total animals with $200-d$ weight & & 13,852 \\
\hline No. of animals in $\mathrm{A}^{-1}$ & & 20,510 \\
\hline
\end{tabular}
MARC I population ${ }^{a}$

aData set 2 , in addition to records in data set 1 , included records from a diallel cross with the Braunvieh, Red Poll, Hereford, and Angus breeds, records from a top cross experiment with calves sired by Charolais and Limousin bulls, and records of animals in the grade-up process to different purebreeds contributing to the composites.

bescription of data set 1 is in Table 2. 
$\mathbf{Z}_{1}, \mathbf{Z}_{\mathbf{M}}$, and $\mathbf{W}$ are incidence matrices with zeros and ones relating observations to genetic additive direct, additive maternal, and permanent environmental effects, respectively. The $\mathbf{Z}_{\mathrm{I}}$ and $\mathbf{Z}_{M}$ were augmented with $\mathbf{0}$ columns for animals without records that were included in the additive relationship matrix.

First and second moments of the model are

$$
\begin{aligned}
& \operatorname{Var}\left[\begin{array}{l}
\mathrm{a} \\
\mathrm{m} \\
\mathrm{c} \\
\mathrm{e}
\end{array}\right]=\left[\begin{array}{llll}
\mathrm{A} \sigma_{\mathrm{a}}^{2} & \mathrm{~A} \sigma_{\mathrm{am}} & 0 & 0 \\
\mathrm{~A} \sigma_{\mathrm{am}} & \mathrm{A} \sigma_{\mathrm{m}}^{2} & 0 & 0 \\
0 & 0 & \mathrm{I}_{\mathrm{n}_{\mathrm{c}}} \sigma_{\mathrm{c}}^{2} & 0 \\
0 & 0 & 0 & \mathrm{I}_{\mathrm{n}} \sigma_{\mathrm{e}}^{2}
\end{array}\right] \\
& \mathrm{E}(\mathrm{y})=\mathrm{X} \beta+\mathrm{Hh}+\mathrm{Q}_{1} \mathrm{~g}+\mathrm{Q}_{M} \mathrm{~d} \text { and } \\
& \operatorname{Var}(\mathrm{y})=\mathrm{Z}_{\mathrm{I}} \mathrm{A} \mathrm{Z}_{\mathrm{I}}^{\prime} \sigma_{\mathrm{a}}^{2}+\mathrm{Z}_{\mathrm{M}} \mathrm{A} \mathrm{Z}_{\mathrm{M}^{\prime} \sigma_{\mathrm{m}}^{2}}^{2}+\mathrm{Z}_{\mathrm{I}} \mathrm{A} \mathrm{Z}_{\mathrm{M}^{\prime}} \sigma_{\mathrm{am}} \\
& +Z_{\mathrm{M}} A Z^{\prime} \sigma_{\mathrm{am}}+\mathrm{WW}^{\prime} \sigma_{\mathrm{c}}^{2}+1 \sigma_{\mathrm{e}}^{2}
\end{aligned}
$$

where

$A$ is the additive genetic relationship matrix obtained using Quaas' (1976) rules,

$I_{n_{c}}$ and $I_{n}$ are identity matrices of sizes equal to the number of dams $\left(n_{c}\right)$ and to the total number of records $(n)$, respectively,

$\sigma_{a}^{2}$ is the additive direct genetic variance,

$\sigma^{2}$ and $\sigma_{c}^{2}$ are the additive genetic and permanent environmental maternal variances,

$\sigma_{\text {am }}$ is the covariance between additive direct and additive maternal genetic effects, and

$\sigma_{\mathrm{e}}^{2}$ is the residual variance.

\section{Estimation of Variance Components}

Variance components were estimated with the MTDFREML programs (Boldman et al., 1993). Estimates are reported only for data set 1 (Table 8 ). For two populations that included the extra data, the differences in the estimates of the variance components with and without the extra data were small; thus, no other analyses with the extra data were run.

\section{Estimation of Genetic Fixed Effects}

Analyses were performed with the MTDFREML programs (Boldman et al., 1993). With estimates of variance components from data set 1 (Table 8 ), solutions for direct and maternal heterosis, direct and maternal breed effects, and their standard errors were computed for data set 1 and data set 2 . The block diagonal part of the inverse of the coefficient matrix of the mixed model equations corresponding to the heterosis and breed effects in the model was obtained, which corresponds to the sampling covariances of the respective estimates. From this submatrix, sampling correlations among the estimates were calculated.

\section{Results and Discussion}

Breed Effects. Estimates of direct and maternal breed effects, as deviations from Angus, using data sets 1 and 2 for birth weight are in Table 9. In general, standard errors of estimates obtained before including the extra data (i.e., those obtained with data set 1) are much larger than for estimates obtained once the data from the diallel and top cross experiments and from the grading up process were considered. Estimates of breed effects from data set 1 for Limousin are different from what was expected. Estimate of the direct breed effect was large positive $(16.16 \pm 4.58)$ and for the maternal effect was large negative $(-9.05 \pm 4.50)$, but with large standard errors. However, estimates of the total Limousin breed effect (i.e., the sums of direct and maternal breed effects) obtained with data sets 1 and 2 are very

\begin{tabular}{|c|c|c|}
\hline Breed & $\begin{array}{l}\text { Period of } \\
\text { births }\end{array}$ & $\begin{array}{l}\text { Animals with } \\
\text { birth weight }\end{array}$ \\
\hline Data set $1^{b}$ & 1968-1992 & 10,867 \\
\hline Angus (A) & 1973-1974 & 129 \\
\hline Hereford $(\mathrm{H})$ & 1973-1974 & 86 \\
\hline Simmental (S) & $\begin{array}{l}1976-1985 \\
1990-1992\end{array}$ & 969 \\
\hline Gelbvieh (G) & 1984 & 46 \\
\hline $\mathrm{H} \times \mathrm{A}$ and reciprocal & 1973-1976 & 293 \\
\hline $\mathrm{S} \times \mathrm{H}$ or $\mathrm{A}$ & $\begin{array}{l}1970-1972 \\
1976-1982\end{array}$ & 1,173 \\
\hline $\mathrm{G} \times \mathrm{H}$ or $\mathrm{A}$ & $\begin{array}{l}1973-1974 \\
1976-1977\end{array}$ & 522 \\
\hline $\mathrm{S} \times(\mathrm{G} \times \mathrm{H}$ or $\mathrm{A})$ & 1976-1982 & 424 \\
\hline $\mathrm{S} \times(\mathrm{HA})$ & 1976-1982 & 268 \\
\hline $\mathrm{S} \times(\mathrm{AH})$ & 1976-1982 & 189 \\
\hline Backcrosses H-A & 1975-1976 & 13 \\
\hline $\mathrm{S} \times(\mathrm{S} \times \mathrm{H}$ or $\mathrm{A})$ & 1972-1977 & 968 \\
\hline$G \times(G \times H$ or $A)$ & 1978-1979 & 7 \\
\hline $\mathrm{S} \times \mathrm{S} \times(\mathrm{S} \times \mathrm{H}$ or $\mathrm{A})$ & 1974-1982 & 1,158 \\
\hline$G \times G \times(G \times H$ or $A)$ & 1984 & 8 \\
\hline Total animals with birth weight & & 17,120 \\
\hline Total animals with $200-d$ weight & & 14,258 \\
\hline No. of animals in $A^{-1}$ & & 21,038 \\
\hline
\end{tabular}
similar (7.11 vs 7.09) and are similar to the estimate

Table 6. Structure of data set 2 for the MARC II population ${ }^{\mathrm{a}}$

${ }^{a}$ Data set 2 , in addition to records in data set 1 , included records from a diallel cross with the Braunvieh, Red Poll, Hereford, and Angus breeds, records from a top cross experiment with calves sired by Simmental and Gelbvieh bulls, and records of animals in the grade-up process to different purebreeds contributing to the composites.

${ }^{\mathrm{b}}$ Description of data set 1 is in Table 3. 
Table 7. Structure of data set 2 for the MARC III population ${ }^{\mathrm{a}}$

\begin{tabular}{|c|c|c|}
\hline Breed & $\begin{array}{l}\text { Period of } \\
\text { births }\end{array}$ & $\begin{array}{l}\text { Animals } \\
\text { with } \\
\text { birth } \\
\text { weight }\end{array}$ \\
\hline Data set $1^{\mathrm{b}}$ & 1968-1992 & 9,322 \\
\hline Angus (A) & 1973-1974 & 129 \\
\hline Hereford $(\mathrm{H})$ & 1973-1974 & 86 \\
\hline Pinzgauer $(P)$ & - & - \\
\hline Red Poll ( R ) & 1973-1974 & 39 \\
\hline $\mathrm{H} \times \mathrm{A}$ and reciprocal & 1973-1976 & 293 \\
\hline $\mathrm{H} \times \mathrm{R}$ and reciprocal & $1973-1976$ & 148 \\
\hline $\mathrm{A} \times \mathrm{R}$ and reciprocal & $1973-1976$ & 182 \\
\hline$H \times(A R)$ & 1975-1976 & 9 \\
\hline$H \times(R A)$ & 1975-1976 & 17 \\
\hline$A \times(H R)$ & 1975-1976 & 6 \\
\hline$A \times(R H)$ & 1975-1976 & 14 \\
\hline Backcrosses H-A & 1975-1976 & 13 \\
\hline $\mathrm{P} \times(\mathrm{PH})$ & 1981-1982 & 109 \\
\hline$P \times(P A)$ & 1980-1982 & 204 \\
\hline Total animals with birth weight & & 10,571 \\
\hline Total animals with $200-d$ weight & & 9,282 \\
\hline No. of animals in $A^{-1}$ & & 14,334 \\
\hline
\end{tabular}

aData set 2 , in addition to records in data set 1 , included records from a diallel cross with the Braunvieh, Red Poll, Hereford, and Angus breeds, and records of animals in the grade-up process to different purebreeds contributing to the composites.

${ }^{b}$ Description of data set 1 is in Table 4.

(6.8) reported by Gregory et al. (1991) using least squares mixed model procedures and with data only from the composite breeds and their contemporary purebreds. The similarity between estimates of total breed effects obtained with the two sets of data, and to the ones reported by Gregory et al. (1991), was true for all breeds.

Corresponding estimates of breed effects for 200-d weight are presented in Table 10. The same patterns discussed for birth weight were observed for 200-d weight. Standard errors for estimates obtained with data set 1 were large. Estimates of total breed effects obtained with the two sets of data are similar and are similar to the ones reported by Gregory et al. (1991). For 200-d weight, the largest differences in the estimates for direct and maternal breed effects obtained with the two sets of data were for the Simmental and Gelbvieh breeds in the MARC II population (Table 10). The estimates obtained with data set 1 for direct breed effects were large negative $(-42.37 \pm 19.35$ and $-46.19 \pm 29.40$ for Simmental and Gelbvieh, respectively), and for the maternal breed effects the estimates were large positive (94.61 \pm 19.34 and $100.68 \pm 29.51$ for Simmental and Gelbvieh, respectively), but in both cases with large standard errors. This result should have been expected due to the poor structure of data set 1 in the MARC II population (Table 3 ) for separating the different genetic fixed effects in the model, resulting in high sampling correlations between the estimates for the direct and maternal breed effects, as will be discussed later. Once the extra data in data set 2 (Table 6 ) was considered, the estimates were more reasonable. Estimates for direct breed effects for Simmental and Gelbvieh, with larger body size than Angus (Cundiff et al., 1986), were now positive $(29.79 \pm 4.38$ and $36.98 \pm 5.64$, respectively), and the estimates for maternal breed effects (36.98 \pm 5.64 and $17.16 \pm 5.21$, respectively) were not as large as the ones obtained with data set 1 .

Most estimates of breed effects obtained with data set 2, for birth and 200-d weights, agree well with previous reports (e.g., Gregory et al., 1978, 1979, 1991; Comerford et al., 1987, 1988; Dearborn et al., 1987). However, some estimates were different from expected. Compared with results reported by Comerford et al. (1988) and Smith et al. (1976), the estimated direct effect for 200-d weight of Limousin is low, and the estimated maternal effect is high (expected to be similar to Angus). The same is true for the estimates of breed effects for 200-d weight of Charolais. Actually, the estimates obtained with data set 1 for 200-d weight for these two breeds are more similar to expected ones than estimates obtained with data set 2 (Table 10). Most of the results reported by Núñez-Domínguez et al. (1993) for weaning weight of breeds evaluated in the Germ Plasm Evaluation Program at MARC agree with the present study, except for breed maternal effects of Simmental and Gelbvieh, which they reported as maternal grandsire means, and the equivalent differences compared with Angus were twice as large as the ones reported here. Some of the inconsistencies could be because data used in the present study did not come from a designed experiment to estimate direct and maternal breed effects. The sum of the two estimates, direct and maternal for each breed, agrees well with the expected

Table 8. Estimates of variance components $\left(\mathrm{kg}^{2}\right)$ for permanent environmental $\left(\sigma_{\mathrm{c}}^{2}\right)$ and residual $\left(\sigma_{\mathrm{e}}^{2}\right)$ effects, additive direct $\left(\sigma_{\mathrm{a}}^{2}\right)$ and maternal $\left(\sigma_{\mathrm{m}}^{2}\right)$ genetic effects and their covariance $\left(\sigma_{\mathrm{a}, \mathrm{m}}\right)$, on birth and 200-d weights of three multibreed populations of beef cattle using data set $1^{\mathrm{a}}$

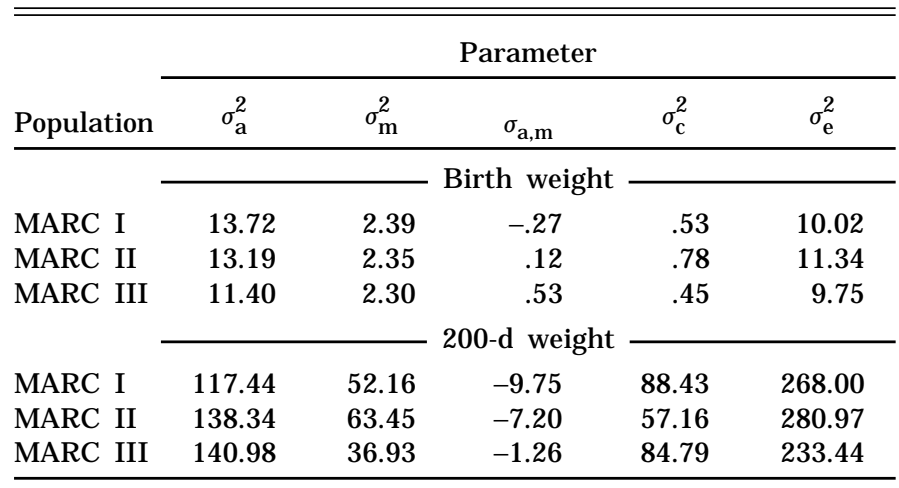

aData set 1 included records of composite animals, their ancestors, and their contemporary purebreds. 
Table 9. Estimates and standard errors of direct and maternal breed effects as deviations from Angus for birth weight $(\mathrm{kg})$ from three multibreed populations of beef cattle, using two sets of data ${ }^{a}$

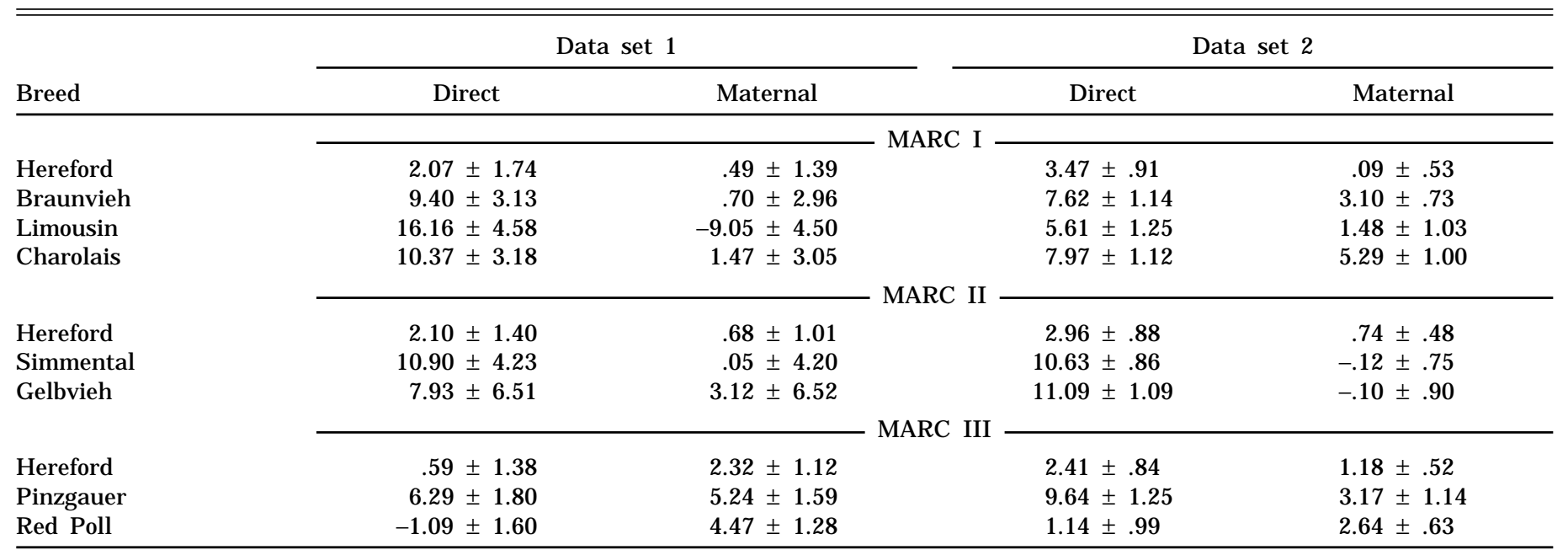

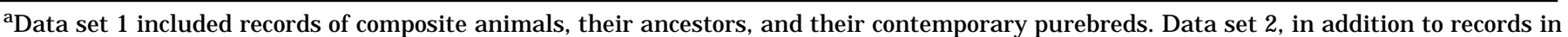
data set 1, included records from a diallel cross with the Braunvieh, Red Poll, Hereford, and Angus breeds, records from a top cross experiment with calves sired by Charolais, Limousin, Simmental, and Gelbvieh bulls, and records of animals in the grade-up process to different purebreeds contributing to the composites.

values (Gregory et al., 1991); however, the crosses available in some cases seem not to allow partition of the breed effects into the part due to the genetic makeup of the calf and the part due to the genetic makeup of the cow.

Heterosis Effects. Estimates of direct and maternal heterosis effects on birth and 200-d weights are presented in Table 11. Estimates obtained with data set 1 have the same problems as estimates obtained with that data set for breed effects. Some estimates for direct and maternal heterosis effects had unexpected negative signs. The most extreme case was for the
MARC II population, for which the estimate for maternal heterosis on 200-d weight was $-17.13 \pm 6.66$, although with a large standard error. Once the extra data in data set 2 were included in the analyses, the results were more reasonable; however, it must be recalled that the assumption was that heterosis effects were the same for all the crosses, which may not be true, but this was all that could be estimated with the data in this study. The unexpected negative signs of estimates for data set 1 could be due to sampling variation, to small sample size, or to multicollinearity, as discussed next.

Table 10. Estimates and standard errors of direct and maternal breed effects as deviations from Angus for 200-d weight $(\mathrm{kg})$ from three multibreed populations of beef cattle, using two sets of data

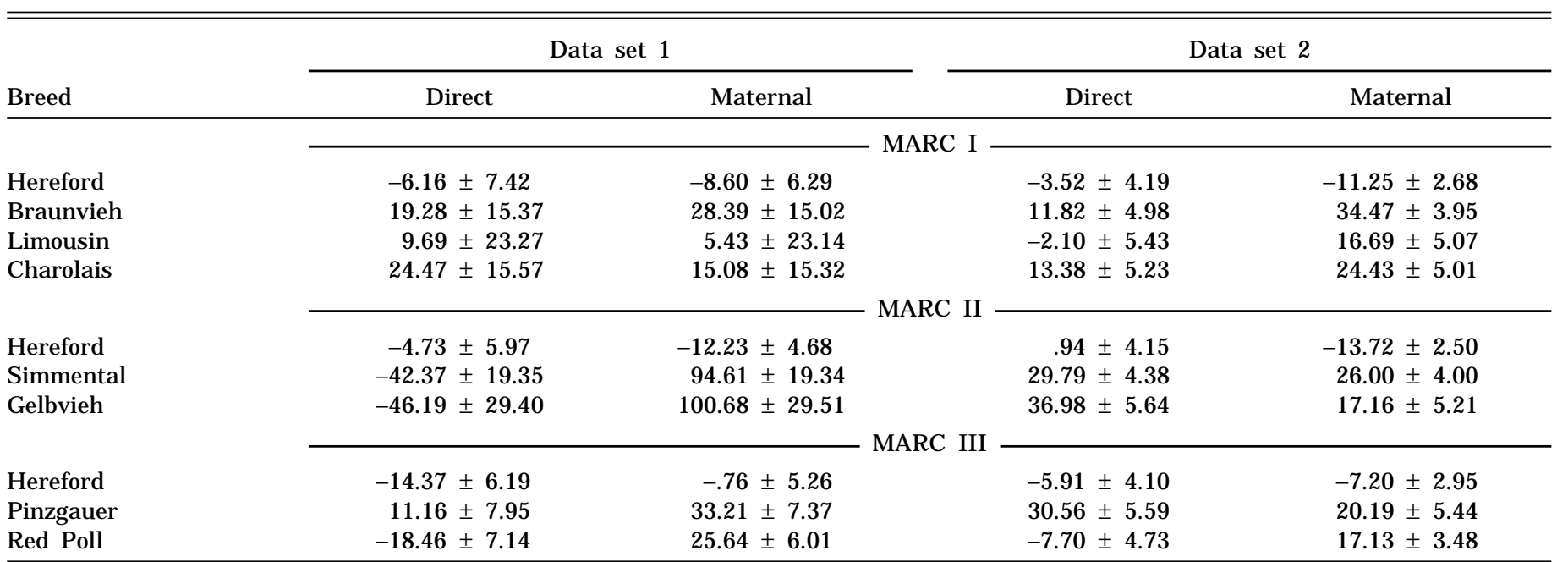

aData set 1 included records of composite animals, their ancestors, and their contemporary purebreds. Data set 2, in addition to records in data set 1 , included records from a diallel cross with the Braunvieh, Red Poll, Hereford, and Angus breeds, records from a top cross experiment with calves sired by Charolais, Limousin, Simmental, and Gelbvieh bulls, and records of animals in the grade-up process to different purebreeds contributing to the composites. 
Table 11. Estimates and standard errors of direct and maternal heterosis effects on birth and 200-d weights $(\mathrm{kg})$ from three multibreed populations of beef cattle, using two sets of data ${ }^{a}$

\begin{tabular}{|c|c|c|c|c|}
\hline \multirow[b]{2}{*}{ Population } & \multicolumn{2}{|c|}{ Data set 1} & \multicolumn{2}{|c|}{ Data set 2} \\
\hline & Direct & Maternal & Direct & Maternal \\
\hline & & - & \multicolumn{2}{|c|}{ - Birth weight } \\
\hline MARC I & $-5.00 \pm 2.08$ & $6.10 \pm 1.89$ & $.78 \pm .29$ & $.43 \pm .28$ \\
\hline MARC II & $-.28 \pm 1.95$ & $.89 \pm 1.37$ & $.29 \pm .32$ & $.08 \pm .24$ \\
\hline MARC III & $2.09 \pm .58$ & $-.21 \pm .59$ & $1.06 \pm .27$ & $.66 \pm .35$ \\
\hline MARC I & $3.50 \pm 10.86$ & $13.80 \pm 9.91$ & $8.74 \pm 1.61$ & $5.93 \pm 1.51$ \\
\hline MARC II & $10.90 \pm 4.23$ & $-17.13 \pm 6.66$ & $12.95 \pm 1.82$ & $5.47 \pm 1.35$ \\
\hline MARC III & $14.15 \pm 2.70$ & $4.26 \pm 2.79$ & $7.97 \pm 1.56$ & $9.89 \pm 1.82$ \\
\hline
\end{tabular}

aData set 1 included records of composite animals, their ancestors, and their contemporary purebreds. Data set 2, in addition to records in data set 1 , included records from a diallel cross with the Braunvieh, Red Poll, Hereford, and Angus breeds, records from a top cross experiment with calves sired by Charolais, Limousin, Simmental, and Gelbvieh bulls, and records of animals in the grade-up process to different purebreeds contributing to the composites.

Table 12. Sampling correlations among estimates of direct $\left(\mathrm{h}^{\mathrm{T}}\right)$ and maternal $\left(\mathrm{h}^{\mathrm{M}}\right)$ heterosis effects, and direct (I) and maternal (M) breed effect differences from Angus for Braunvieh (B), Hereford (H), Limousin (L), and Charolais $(\mathrm{C})$, for birth weight of the MARC I population, using data set $1^{\text {a }}$ (above the diagonal) and data set $2^{\mathrm{b}}$ (below the diagonal)

\begin{tabular}{|c|c|c|c|c|c|c|c|c|c|c|}
\hline$h^{\prime}$ & & -.96 & -.78 & -.03 & -.89 & -.78 & .83 & .04 & .91 & .82 \\
\hline $\mathrm{B}^{\prime}$ & -.22 & .15 & & .30 & .86 & .89 & -.95 & -.26 & -.85 & -.89 \\
\hline $\mathrm{H}^{\prime}$ & -.03 & .04 & .40 & & .22 & .30 & -.22 & -.89 & -.16 & -.22 \\
\hline $\mathrm{L}^{\prime}$ & -.19 & .18 & .44 & .39 & & .86 & -.88 & -.19 & -.97 & -.87 \\
\hline $\mathrm{H}^{\mathrm{M}}$ & .02 & -.03 & -.35 & -.88 & -.34 & -.36 & .34 & & .18 & .24 \\
\hline$L^{M}$ & .25 & -.24 & -.39 & -.23 & -.73 & -.44 & .46 & .26 & & .89 \\
\hline$C^{M}$ & .31 & .03 & -.41 & -.22 & -.38 & -.82 & .50 & .26 & .47 & \\
\hline
\end{tabular}

${ }^{a}$ Data set 1 included records of composite animals, their ancestors, and their contemporary purebreds.

b Data set 2, in addition to records in data set 1, included records from a diallel cross with the Braunvieh, Red Poll, Hereford, and Angus breeds, records from a top cross experiment with calves sired by Charolais and Limousin bulls, and records of animals in the grade-up process to different purebreeds contributing to the composite.

Table 13. Sampling correlations among estimates of direct $\left(\mathrm{h}^{\mathrm{I}}\right)$ and maternal $\left(\mathrm{h}^{\mathrm{M}}\right)$ heterosis effects, and direct (I) and maternal (M) breed effect differences from Angus for Simmental (S), Hereford $(\mathrm{H})$, and Gelbvieh $(\mathrm{G})$, for 200-d weight of the MARC II population, using data set $1^{\text {a }}$ (above the diagonal) and data set $2^{\mathrm{b}}$ (below the diagonal)

\begin{tabular}{|c|c|c|c|c|c|c|c|c|}
\hline $\begin{array}{l}\text { Genetic } \\
\text { effect }\end{array}$ & $h^{\prime}$ & $\mathrm{h}^{\mathrm{M}}$ & $S^{\prime}$ & $\mathrm{H}^{\prime}$ & $\mathrm{G}^{\prime}$ & $\mathrm{S}^{\mathrm{M}}$ & $\mathrm{H}^{\mathrm{M}}$ & $\mathrm{G}^{\mathrm{M}}$ \\
\hline $\mathrm{h}^{\prime}$ & & -.93 & -.92 & -.03 & -.92 & .92 & .03 & .92 \\
\hline $\mathrm{h}^{\mathrm{M}}$ & -.44 & & .87 & .04 & .80 & -.87 & -.04 & -.80 \\
\hline $\mathrm{S}^{\prime}$ & -.45 & .13 & & .17 & .93 & -.98 & -.15 & -.92 \\
\hline $\mathrm{H}^{\prime}$ & -.05 & .04 & .52 & & .09 & -.12 & -.85 & -.05 \\
\hline $\mathrm{G}^{\prime}$ & -.53 & .38 & .69 & .40 & & -.93 & -.07 & -.99 \\
\hline $\mathrm{S}^{\mathrm{M}}$ & .54 & -.19 & -.76 & -.31 & -.59 & & .14 & .94 \\
\hline $\mathrm{H}^{\mathrm{M}}$ & .06 & -.03 & -.46 & -.86 & -.35 & .36 & & .06 \\
\hline $\mathrm{G}^{\mathrm{M}}$ & .59 & -.41 & -.55 & -.23 & -.82 & .62 & .27 & \\
\hline
\end{tabular}

aData set 1 included records of composite animals, their ancestors, and their contemporary purebreds.

${ }^{b}$ Data set 2, in addition to records in data set 1, included records from a diallel cross with the Braunvieh, Red Poll, Hereford, and Angus breeds, records from a top cross experiment with calves sired by Simmental and Gelbvieh bulls, and records of animals in the grade-up process to different purebreeds contributing to the composite. 
Table 14. Sampling correlations among estimates of direct $\left(\mathrm{h}^{\mathrm{I}}\right)$ and maternal $\left(\mathrm{h}^{\mathrm{M}}\right)$ heterosis effects, and direct (I) and maternal (M) breed effect differences from Angus for Pinzgauer (P), Hereford (H), and Red Poll (R), for 200-d weight of the MARC III population, using data set $1^{\text {a }}$ (above the diagonal) and data set $2^{\text {b }}$ (below the diagonal)

\begin{tabular}{|c|c|c|c|c|c|c|c|c|}
\hline$h^{\prime}$ & & -.68 & -.44 & -.12 & -.32 & .45 & .17 & .37 \\
\hline $\mathrm{Pl}^{\mathrm{I}}$ & -.16 & -.04 & & .55 & .63 & -.86 & -.51 & -.62 \\
\hline $\mathrm{H}^{\prime}$ & -.02 & .06 & .41 & & .57 & -.50 & -.86 & -.54 \\
\hline $\mathrm{R}^{\prime}$ & -.18 & .16 & .42 & .47 & & -.59 & -.53 & -.84 \\
\hline $\mathrm{R}^{\mathrm{M}}$ & .18 & -.14 & -.35 & -.39 & -.77 & .42 & .48 & \\
\hline
\end{tabular}

aData set 1 included records of composite animals, their ancestors, and their contemporary purebreds.

bData set 2, in addition to records in data set 1, included records from a diallel cross with the Braunvieh, Red Poll, Hereford, and Angus breeds, and records of animals in the grade-up process to different purebreeds contributing to the composite.

Sampling Correlations. The large standard errors and the unexpected large estimates of breed and heterosis effects with data set 1 can be explained by the large sampling correlations among the estimates. As an example, the sampling correlation matrices of estimates for breed and heterosis effects obtained with the two sets of data are presented in Table 12 for birth weight of the MARC I population, in Table 13 for 200-d weight of the MARC II population, and in Table 14 for 200-d weight of the MARC III population. There were large sampling correlations among the estimates obtained with data set 1, especially between estimates of direct and maternal heterosis and between estimates of direct and maternal breed effects for the same breed, which had sampling correlations close to -1 . This is the reason estimates of direct and maternal breed effects from data set 1 tended to go in opposite directions in some cases (e.g., for birth weight of Limousin [Table 9] and 200-d weight of Simmental and Gelbvieh [Table 10]). The problem disappeared when the extra data were included in data set 2, even though the sampling correlations between estimates of direct and maternal breed effects in the same breed still were approximately -.8 , which may be the most this correlation can be reduced.

Although the heterosis effects and differences of breed effects are estimable with the models used for the present analyses, as corroborated by expectations of solutions to the mixed model equations, the large sampling correlations for estimates obtained with data set 1 indicate some degree of confounding between direct and maternal genetic effects. The present model is a simplification of the model proposed by Dickerson (1969). Under Dickerson's model, most of the specific heterosis and differences of breed effects would not be estimable. Accounting for differences among breeds by Westell's algorithm (Westell et al., 1988; Van Vleck, 1990) is equivalent to fitting breed effects as covariates in the model, as was done in the present study.
Lack of enough information to separate direct and maternal breed effects in multibreed populations when predicting EPD for comparisons of animals across breeds may result in incorrect ranking of animals. Estimates of breed differences form part of those EPD (Arnold et al., 1992) and any error in estimation of those differences will be repeated in every comparison of animals from the corresponding pair of breeds.

\section{Implications}

Even with a simplified model, separation of estimates of mean genetic effects on traits of multibreed populations of beef cattle into those due to the genetic make-up of the calf and those due to the genetic makeup of the dam requires data from a variety of crosses. In beef cattle, there are limited numbers of breeds or crosses in any herd. Thus, estimation of direct and maternal breed genetic effects from field data sets may not be possible. The development of an evaluation system for using crossbred records will require incorporation of information from designed crossbreeding experiments in some way.

\section{Literature Cited}

Arnold, J. W., J. K. Bertrand, and L. L. Benyshek. 1992. Animal model for genetic evaluation of multibreed data. J. Anim. Sci. 70:3322.

Boldman, K. G., L. A. Kriese, L. D. Van Vleck, and S. D. Kachman. 1993. A manual for use of MTDFREML. A set of programs to obtain estimates of variances and covariances. ARS, USDA, Washington, DC.

Comerford, J. W., L. L. Benyshek, J. K. Bertrand, and M. H. J ohnson. 1988. Evaluation of performance characteristics in a diallel among Simmental, Limousin, Polled Hereford and Brahman beef cattle. I. Growth, hip height and pelvic size. J. Anim. Sci. 66:293.

Comerford, J. W., J. K. Bertrand, L. L. Benyshek, and M. H. J ohnson. 1987. Reproductive rates, birth weight, calving ease 
and 24-h calf survival in a four-breed diallel among Simmental, Limousin, Polled Hereford and Brahman beef cattle. J. Anim. Sci. 64:65.

Cundiff, L. V., K. E. Gregory, R. M. Koch, and G. E. Dickerson. 1986. Genetic diversity among cattle breeds and its use to increase beef production efficiency in a temperate environment. Proc. 3rd World Congr. Genet. Appl. Livest. Prod. 9:271.

Dearborn, D. D., K. E. Gregory, L. V. Cundiff, and R. M. Koch. 1987. Maternal heterosis and grandmaternal effects in beef cattle: Preweaning traits. J. Anim. Sci. 65:33.

Dickerson, G. E. 1969. Experimental approaches in utilizing breed resources. Anim. Breed. Abstr. 37:191.

Elzo, M. A., and T. R. Famula. 1985. Multibreed sire evaluation procedures within a country. J. Anim. Sci. 60:942.

Golden, B. L., J . W. Arnold, R. M. Bourden, W. M. Snelling, and J . S. Brinks. 1994. Hybrid beef cattle EPD production in the United States. Proc. of the Fourth Genetic Prediction Workshop, Kansas City, MO.

Gregory, K. E., L. V. Cundiff, and R. M. Koch. 1991. Breed effects and heterosis in advanced generations of composite populations for preweaning traits of beef cattle. J. Anim. Sci. 69:947.

Gregory, K. E., L. V. Cundiff, R. M. Koch, D. B. Laster, and G. M. Smith. 1978. Heterosis and breed maternal and transmitted effects in beef cattle. I. Preweaning traits. J. Anim. Sci. 47: 1031.

Gregory, K. E., G. M. Smith, L. V. Cundiff, R. M. Koch, and D. B. Laster. 1979. Characterization of biological types of cattleCycle III: I. Birth and weaning traits. J. Anim. Sci. 48:271.

Núñez-Domínguez, R., L. D. Van Vleck, K. G. Boldman, and L. V. Cundiff. 1993. Correlations for genetic expression for growth of calves of Hereford and Angus dams using a multivariate animal model. J. Anim. Sci. 71:2330.

Quaas, R. L. 1976. Computing the diagonal elements and inverse of a large numerator relationship matrix. Biometrics 32:949.

Smith, G. M., D. B. Laster, and K. E. Gregory. 1976. Characterization of biological types of cattle. I. Dystocia and preweaning growth. J. Anim. Sci. 43:27.

Van Vleck, L. D. 1990. Breeding value prediction with maternal genetic groups. J. Anim. Sci. 68:3998.

Westell, R. A., R. L. Quaas, and L. D. Van Vleck. 1988. Genetic groups in an animal model. J. Dairy Sci. 71:1310.

Wilton, J. W., and S. P. Miller. 1994. Multi-breed evaluations for beef cattle. Proc. of the Fourth Genetic Prediction Workshop, Kansas City, MO. 